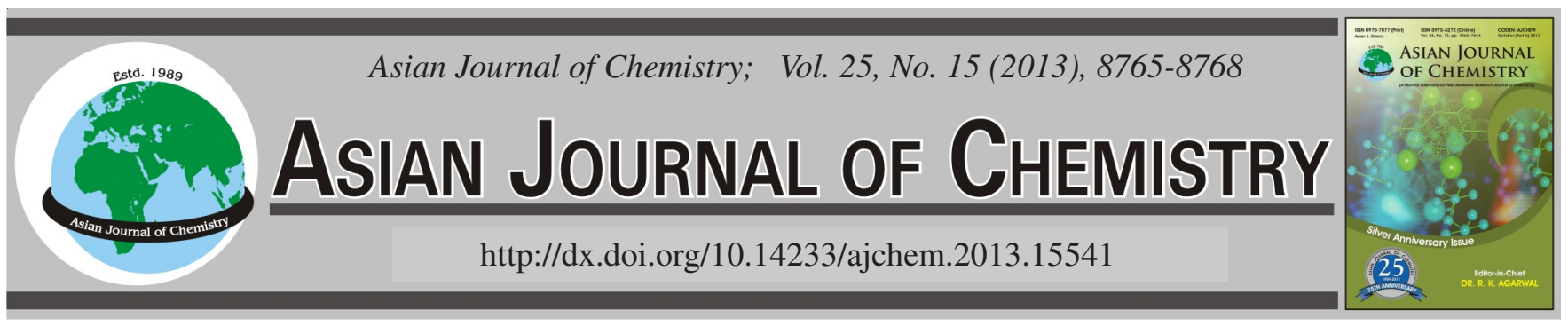

\title{
Adsorption of Mercury on Activated Carbon in Simulated Flue Gas with Continuous Components Change
}

\author{
Chang-Xing Hu ${ }^{1, *}$, Jin-Song Zhou ${ }^{2}$, Jian-XIN Li ${ }^{1}$, Yong-Chuan Wang ${ }^{1}$, \\ JiAo Zheng ${ }^{1}$, Mei-JuAn XU ${ }^{1}$, Zhong-YAng LuO ${ }^{2}$ and Ke-FA $\mathrm{CEN}^{2}$
}

${ }^{1}$ Ningbo Institute of Technology, Zhejiang University, Ningbo 315100, P.R. China

${ }^{2}$ State Key Laboratory of Clean Energy Utilization, Zhejiang University, Hangzhou 310027, P.R. China

*Corresponding author: E-mail: huchx@ zju.edu.cn

\begin{abstract}
This paper focused on the influence of flue gas component change on elemental mercury $\left(\mathrm{Hg}^{0}\right)$ adsorption by powder activated carbon from apricot's shell and discussed the $\mathrm{Hg}^{0}$ adsorption characteristics and mechanism of activated carbon. Experimental results showed that activated carbon from apricot's shell had no $\mathrm{Hg}^{0}$ adsorption ability in the non-oxidizing atmosphere, such as $\mathrm{N}_{2}, \mathrm{~N}_{2}+\mathrm{CO}_{2}$ etc. Though the influence on homogeneous oxidation reaction of $\mathrm{Hg}^{0}$ was limited, $\mathrm{NO}_{2}$ was the key factor on heterogeneous catalytic oxidation reaction of $\mathrm{Hg}^{0}$ on the surface of activated carbon. It was easy to form $\mathrm{NO}_{2}$ by reaction between the $\mathrm{NO}$ and $\mathrm{O}_{2}$. It could also enhance the $\mathrm{Hg}^{0}$ adsorption ability of activated carbon through preloading $\mathrm{NO}_{2}$ on the surface. Based on these experimental results, it finely proved that $\mathrm{Hg}^{0}$ adsorption by activated carbon was a heterogeneous catalytic oxidation reaction.
\end{abstract}

Key Words: Apricot shell, Activated carbon, Elemental mercury, Oxidization, Chemical adsorption.

\section{INTRODUCTION}

Mercury emission from coal fired is one of the main anthropogenic mercury pollution sources. There are three types of mercury speciation existing in the flue gas, zero-valent mercury $\left(\mathrm{Hg}^{0}\right)$, bivalent mercury $\left(\mathrm{Hg}^{2+}\right)$ and particle mercury $\left(\mathrm{Hg}^{\mathrm{p}}\right)$. The ratio of mercury speciation will transform with the change of flue gas components, temperature and time, etc. ${ }^{1}$. Mercury speciation is the key influence factor on choosing the flue gas mercury control technology. $\mathrm{Hg}^{0}$ is the main source to induce global mercury pollution, because it is difficult to be controlled for its insolubility in water and stabilization within 1-2 years in the atmosphere. Adsorbent injection mercury control technology has widely applicable and can satisfy the higher mercury emissions control standard, which can be used alone or in combination of other technologies and is one of the effective flue gas mercury control technologies.

The $\mathrm{Hg}^{0}$ adsorption mechanism by activated carbon in different flue gas is very important for developing new low-cost carbon based adsorbents. Many papers $^{2-9}$ reported the researches on mercury adsorption mechanism of carbon based adsorbents. It found that some flue gas components could always promote adsorption of mercury by activated carbon in different conditions ${ }^{10,11}$. The latest research ${ }^{4}$ showed that in the non-oxidizing atmosphere and without oxidizing elements on the surface, activated carbon had no $\mathrm{Hg}^{0}$ adsorption ability and physical adsorption process did not exist between the activated carbon and $\mathrm{Hg}^{0}$. Further research found activated carbon had efficient $\mathrm{Hg}^{0}$ adsorption ability in simulated flue gas and $\mathrm{Hg}^{2+}$ was almost the only speciation at the outlet of fixed bed when $\mathrm{Hg}^{0}$ adsorption on activated carbon was saturated $^{12}$. It showed that the chemical oxidation adsorption existed in the process of activated carbon adsorption of $\mathrm{Hg}^{0}$.

This paper mainly discussed the $\mathrm{Hg}^{0}$ adsorption characteristics of powder activated carbon from apricot's shell (ASAC) in simulated flue gas with continuous change of components. It focused on the influence of flue gas component change on mercury adsorption by AS-AC and the mercury adsorption mechanism of activated carbon, which would be helpful to develop effective low-cost carbon-based adsorbents.

\section{EXPERIMENTAL}

Experimental setup of adsorption: The bench-scale $\mathrm{Hg}$ adsorption experimental setup is shown in Fig. 1 including simulated flue gas, fixed adsorption bed, flue gas $\mathrm{Hg}$ continuous emission monitor (CEM), conventional flue gas pollution, adsorption temperature control system and tail gas treatment, etc. The experimental setup is stable and reliable ${ }^{13}$.

The simulated flue gas consisted of three parts: conventional flue gas components, $\mathrm{H}_{2} \mathrm{O}$ and $\mathrm{Hg}^{0}$ source. The simulated 


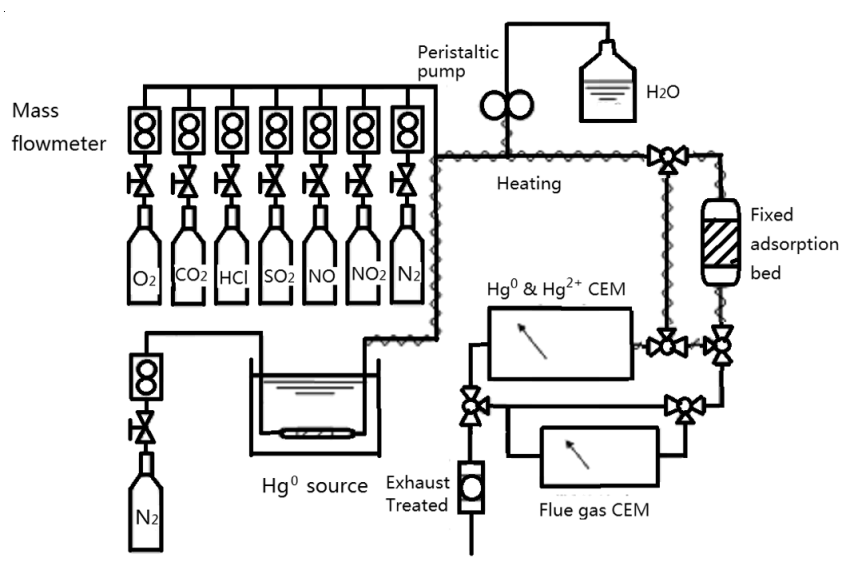

Fig. 1. Bench-scale experiment system of mercury adsorption on sorbent

conventional flue gas components, such as $\mathrm{N}_{2}, \mathrm{CO}_{2}, \mathrm{O}_{2}, \mathrm{SO}_{2}$, $\mathrm{NO}, \mathrm{NO}_{2}$ and $\mathrm{HCl}$, were adjusted by mass flowmeters of the standard gas sources. $\mathrm{H}_{2} \mathrm{O}$ was added to the simulated flue gas using a peristaltic pump which transferred water into the glass tube wrapped with heating line. $\mathrm{Hg}^{0}$ was generated by a

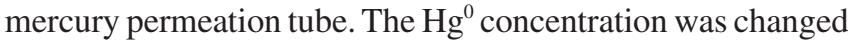
by altering the temperature of permeation tube or the flow rate of carrier gas.

The fixed adsorption bed was made by silicate glass and quartz filter, whose height was $80 \mathrm{~mm}$ and inner diameter was $10 \mathrm{~mm}$. The pore diameter of quartz filter was less than 0.05 $\mathrm{mm}$ and the filter could hold the activated carbon. In this study, the AS-AC made by steam activated method was used. Steam activation is a common activation technique for $\mathrm{AC}$ production and is effective for creating more surface area physically by opening up more micropores. The surfaces of AS-AC had no specific active element besides some possible hydrogen and oxygen elements according to their steam activation method. The surface physical characteristics of AS-AC are given in Table-1.

\begin{tabular}{cccccc}
\multicolumn{7}{c}{ TABLE-1 } \\
SURFACE PHYSICAL CHARACTERISTICS OF AS-AC \\
\hline Sorbent & $\begin{array}{c}\text { Specific } \\
\text { surface } \\
\text { area } \\
\left(\mathrm{m}^{2} / \mathrm{g}\right)\end{array}$ & $\begin{array}{c}\text { Pore } \\
\text { volume } \\
\left(\mathrm{cm}^{3} / \mathrm{g}\right)\end{array}$ & $\begin{array}{c}\text { Micropore } \\
\text { volume } \\
(<20 \AA) \\
\left(\mathrm{cm}^{3} / \mathrm{g}\right)\end{array}$ & $\begin{array}{c}\text { Particle } \\
\text { size } \\
(\mathrm{mm})\end{array}$ & $\begin{array}{c}\text { Porosity } \\
(\%)\end{array}$ \\
\hline AS-AC & 1070 & 0.81 & 0.48 & 0.08 & 57 \\
\hline
\end{tabular}

A continuous emission monitor of DM/6A/MS/1A was used to measure mercury in experiments. The continuous emission monitor has the additional capability of determining mercury speciation in the sample gas stream. Firstly, the sample gas is washed by a potassium chloride solution to capture the divalent mercury. Secondly, the washed sample gas passes through a gas-liquid separator and a potassium hydroxide scrubber to remove interferential gases such as $\mathrm{SO}_{2}$. Thirdly, the remaining sample gas passes through a chiller to remove moisture and the CVAAS (cold vopour generation atomic absorption spectrometry) detector to make a measurement of gaseous $\mathrm{Hg}^{0}$. On the other hand, the $\mathrm{KCl}$ solution containing the $\mathrm{Hg}^{2+}$ reacts with a tin chloride solution to reduce the $\mathrm{Hg}^{2+}$ to the gaseous $\mathrm{Hg}^{0}$. The gaseous $\mathrm{Hg}^{0}$ is transported by the carrier gas passing through a gas-liquid separator and a $\mathrm{KOH}$ scrubber to remove interferential gases. After dehumidification, the carrier gas with $\mathrm{Hg}^{0}$ passes through another CVAAS detector to make a measurement of $\mathrm{Hg}^{2+}$ in the flue gas stream. The CEM with automatic zero adjustment has a nominal range of $0.1-1000 \mu \mathrm{g} / \mathrm{m}^{3}$ and it is calibrated by an internal permeation device with the response time of less than $1 \mathrm{~min}$ and with the sensitivity of $0.1 \mu \mathrm{g} / \mathrm{m}^{3}$.

These conventional gases, $\mathrm{CO}_{2}, \mathrm{O}_{2}, \mathrm{SO}_{2}, \mathrm{NO}$ and $\mathrm{NO}_{2}$, were continuously measured by NGA 2000 MLT Series. The concentrations of $\mathrm{HCl}$ and $\mathrm{H}_{2} \mathrm{O}$ were determined according to concentration and flow rate of corresponding standard gases. In the experimental system, all gas pipelines and fixed bed were heated to desired temperature. The tail gas was treated before emitting into the atmosphere.

Experimental process: The temperature of adsorption bed and gas pipelines was set at $130^{\circ} \mathrm{C}$. The $0.0505 \mathrm{~g} \mathrm{AS}-\mathrm{AC}$ was used as the sorbent. The total flow was controlled at 1.3 $\mathrm{L} /$ min including $300 \mathrm{~mL} / \mathrm{min} \mathrm{N}_{2}$ gas for carrying $\mathrm{Hg}^{0}$. The continuous change process of flue gas components was divided into 17 phases (Table-2). It shows the adsorption condition, components of simulated flue gas and the corresponding experimental time.

\begin{tabular}{|c|c|c|c|}
\hline \multicolumn{4}{|c|}{$\begin{array}{c}\text { TABLE-2 } \\
\text { CONTINUOUS CHANGE OF FLUE GAS COMPONENTS } \\
\text { DURING THE ADSORPTION PROCESS }\end{array}$} \\
\hline Phase & $\begin{array}{c}\text { Through } \\
\text { FAD }^{\mathrm{a}} \\
\end{array}$ & Components of simulated flue gas & $\begin{array}{l}\text { Time } \\
(\mathrm{min}) \\
\end{array}$ \\
\hline 1 & No & $\mathrm{N}_{2}+\mathrm{Hg}^{0}+\mathrm{H}_{2} \mathrm{O}$ & $0-13$ \\
\hline 2 & Yes & $\mathrm{N}_{2}+\mathrm{Hg}^{0}+\mathrm{H}_{2} \mathrm{O}$ & $14-33$ \\
\hline 3 & Yes & $\mathrm{CO}_{2}+\mathrm{N}_{2}+\mathrm{Hg}^{0}+\mathrm{H}_{2} \mathrm{O}$ & $34-60$ \\
\hline 4 & Yes & $\mathrm{O}_{2}+\mathrm{CO}_{2}+\mathrm{N}_{2}+\mathrm{Hg}^{0}+\mathrm{H}_{2} \mathrm{O}$ & $61-88$ \\
\hline 5 & Yes & $\mathrm{SO}_{2}+\mathrm{O}_{2}+\mathrm{CO}_{2}+\mathrm{N}_{2}+\mathrm{Hg}^{0}+\mathrm{H}_{2} \mathrm{O}$ & $89-120$ \\
\hline 6 & Yes & $\mathrm{NO}_{2}+\mathrm{SO}_{2}+\mathrm{O}_{2}+\mathrm{CO}_{2}+\mathrm{N}_{2}+\mathrm{Hg}^{0}+\mathrm{H}_{2} \mathrm{O}$ & $121-173$ \\
\hline 7 & Yes & $\begin{array}{l}\mathrm{NO}+\mathrm{NO}_{2}+\mathrm{SO}_{2}+\mathrm{O}_{2}+ \\
\mathrm{CO}_{2}+\mathrm{N}_{2}+\mathrm{Hg}^{0}+\mathrm{H}_{2} \mathrm{O}\end{array}$ & $174-181$ \\
\hline 8 & Yes & $\begin{array}{l}\mathrm{HCl}+\mathrm{NO}+\mathrm{NO}_{2}+\mathrm{SO}_{2}+\mathrm{O}_{2}+ \\
\mathrm{CO}_{2}+\mathrm{N}_{2}+\mathrm{Hg}^{0}+\mathrm{H}_{2} \mathrm{O}\end{array}$ & $182-194$ \\
\hline 9 & No & $\begin{array}{l}\mathrm{HCl}+\mathrm{NO}+\mathrm{NO}_{2}+\mathrm{SO}_{2}+\mathrm{O}_{2}+ \\
\mathrm{CO}_{2}+\mathrm{N}_{2}+\mathrm{Hg}^{0}+\mathrm{H}_{2} \mathrm{O}\end{array}$ & 195-199 \\
\hline 10 & Yes & $\begin{array}{l}\mathrm{HCl}+\mathrm{NO}+\mathrm{NO}_{2}+\mathrm{SO}_{2}+\mathrm{O}_{2}+ \\
\mathrm{CO}_{2}+\mathrm{N}_{2}+\mathrm{Hg}^{0}+\mathrm{H}_{2} \mathrm{O}\end{array}$ & 200-208 \\
\hline 11 & Yes & $\begin{array}{l}\mathrm{HCl}+\mathrm{NO}+\mathrm{SO}_{2}+\mathrm{O}_{2}+\mathrm{CO}_{2}+\mathrm{N}_{2}+ \\
\mathrm{Hg}^{0}+\mathrm{H}_{2} \mathrm{O}\end{array}$ & $209-227$ \\
\hline 12 & Yes & $\mathrm{HCl}+\mathrm{NO}+\mathrm{SO}_{2}+\mathrm{CO}_{2}+\mathrm{N}_{2}+\mathrm{Hg}^{0}+\mathrm{H}_{2} \mathrm{O}$ & $228-238$ \\
\hline 13 & Yes & $\mathrm{HCl}+\mathrm{SO}_{2}+\mathrm{CO}_{2}+\mathrm{N}_{2}+\mathrm{Hg}^{0}+\mathrm{H}_{2} \mathrm{O}$ & $239-292$ \\
\hline 14 & Yes & $\mathrm{HCl}+\mathrm{CO}_{2}+\mathrm{N}_{2}+\mathrm{Hg}^{0}+\mathrm{H}_{2} \mathrm{O}$ & 293-312 \\
\hline 15 & Yes & $\mathrm{CO}_{2}+\mathrm{N}_{2}+\mathrm{Hg}^{0}+\mathrm{H}_{2} \mathrm{O}$ & $313-323$ \\
\hline 16 & Yes & $\mathrm{N}_{2}+\mathrm{Hg}^{0}+\mathrm{H}_{2} \mathrm{O}$ & $324-395$ \\
\hline 17 & No & $\mathrm{N}_{2}+\mathrm{Hg}^{0}+\mathrm{H}_{2} \mathrm{O}$ & $396-400$ \\
\hline
\end{tabular}

${ }^{\mathrm{a}} \mathrm{FAD}$ : fixed adsorption bed.

\section{RESULTS AND DISCUSSION}

The experimental study of $\mathrm{Hg}^{0}$ adsorption characteristics of AS-AC in simulated flue gas with continuous change of components could be divided into three processes. The first was to add components into simulated flue gas, respectively from phase 2-8. The second was simulated flue gas passing in bypass, i.e., phase 9 . The third was to remove components from simulated flue gas, respectively from phase 10-16.

In the experimental process, the concentrations of five flue gas components were recorded (Fig. 2). The horizontal 


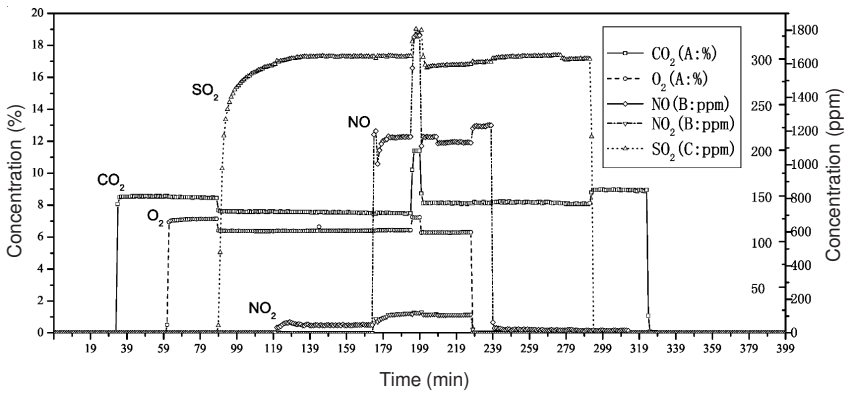

Fig. 2. Concentration change of five conventional flue gas components

ordinate denotes the experimental time ( $\mathrm{min})$. There are three vertical coordinates of $\mathrm{A}, \mathrm{B}$ and $\mathrm{C}$ axis. A shows the concentrations $(\%)$ of $\mathrm{CO}_{2}$ and $\mathrm{O}_{2} ; \mathrm{B}$ shows the concentrations (ppm) of $\mathrm{NO}$ and $\mathrm{NO}$; and $\mathrm{C}$ shows the concentration (ppm) of $\mathrm{SO}_{2}$. According to the Table-2, Fig. 2 shows the outlet concentrations of fixed adsorption bed at different phases. At the $9^{\text {th }}$ phase, the flue gas did not through the adsorption bed. The concentrations of $\mathrm{HCl}$ and $\mathrm{H}_{2} \mathrm{O}$ were not monitored and their original concentrations were $50 \mathrm{ppm}$ and $10 \%$, respectively.

The concentrations of $\mathrm{Hg}^{0}$ and $\mathrm{Hg}^{2+}$ during the whole experimental process were shown as Fig. 3 . The $\mathrm{Hg}^{2+}$ concentration almost did not change, which meant that no $\mathrm{Hg}^{2+}$ passed through the adsorption fixed bed.

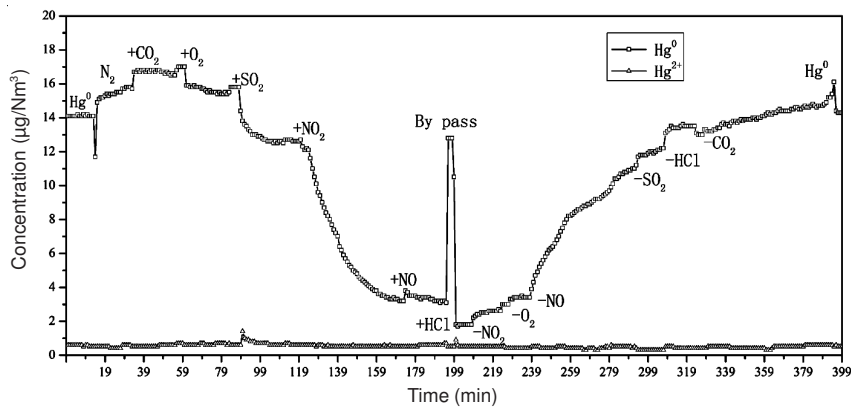

Fig. 3. Concentrations of $\mathrm{Hg}^{0}$ and $\mathrm{Hg}^{2+}$ during the whole experimental process

$\mathrm{Hg}^{\mathbf{0}}$ adsorption when flue gas components added one by one: As shown in Fig. 3, the AS-AC had no $\mathrm{Hg}^{0}$ adsorption ability in the simulated flue gas atmosphere of $\mathrm{N}_{2}, \mathrm{~N}_{2}+\mathrm{CO}_{2}$, or $\mathrm{N}_{2}+\mathrm{CO}_{2}+\mathrm{O}_{2}$ from the 2nd to 4 th phase, which was very similar with the reported papers ${ }^{4,12}$. When $\mathrm{SO}_{2}$ was added at the 5th phase, the concentration of $\mathrm{Hg}^{0}$ decreased a little, which meant that $\mathrm{SO}_{2}$ could promote the $\mathrm{Hg}^{0}$ adsorption by AS-AC. In the same time, $\mathrm{Hg}^{2+}$ appeared. The key point of adsorption process could be understood as reaction (1), which meant that $\mathrm{SO}_{2}$ could oxidize the $\mathrm{Hg}^{0}$ to $\mathrm{Hg}^{2+}$ with the action of $\mathrm{O}_{2}$ on the surface of AS-AC.

$$
\mathrm{SO}_{2}+\mathrm{O}_{2}+\mathrm{Hg} \longrightarrow \mathrm{HgSO}_{4}
$$

At the 6th phase, the $\mathrm{Hg}^{0}$ adsorption ability of AS-AC increased substantially when $\mathrm{NO}_{2}$ was added. According to the concentration change of flue gas components (Fig. 2 and Table-3), the $\mathrm{NO}_{2}$ concentration at the outlet of adsorption bed was only $0.1 \mathrm{ppm}$ far less than the original $\mathrm{NO}_{2}$ concentration of $22.2 \mathrm{ppm}$ in the 9 th phase. At the same time, the NO concentration at the outlet of adsorption bed was $8.7 \mathrm{ppm}$ though NO was not added in the simulated flue gas at this phase.

Many researchers ${ }^{14-18}$ believed that $\mathrm{O}_{2}, \mathrm{NO}_{2}$ and $\mathrm{NO}$ had less effect on the gaseous homogeneous oxidizing reaction of $\mathrm{Hg}^{0}$ because there were some restrictions of reaction kinetics among them. However, they played a key role in the heterogeneous oxidizing reaction of $\mathrm{Hg}^{0}{ }^{19,20}$. Regarding the concentration change of $\mathrm{Hg}^{0}, \mathrm{NO}_{2}$ and $\mathrm{NO}$, it could be considered that $\mathrm{NO}_{2}$ oxidized $\mathrm{Hg}^{0}$ on the surface of AS-AC and generated NO simultaneously. The reaction process was as the following eqn. 2.

$$
\mathrm{Hg}+\mathrm{NO}_{2} \stackrel{\text { Con the furface of } \mathrm{AC}}{\longrightarrow} \mathrm{HgO}+\mathrm{NO}
$$

$\mathrm{NO}$ was added at the 7 th phase. As a result, $\mathrm{NO}_{2}$ concentration rose from 0.1 to $14.0 \mathrm{ppm}$ with the common function of $\mathrm{O}_{2}$ through eqn. 3. The conversion efficiencies of $\mathrm{Hg}^{0}$ to $\mathrm{Hg}^{2+}$ at the 6th phase and the 7 th phase were almost same as $78 \%$. The increment of $\mathrm{NO}_{2}$ did not further promote the $\mathrm{Hg}^{0}$ adsorption, which was mainly because that the existing $\mathrm{NO}_{2}$ concentration (original was $22.2 \mathrm{ppm}$ ) was much higher than $\mathrm{Hg}^{0}$ concentration $\left(c a .14 .1 \mu \mathrm{g} / \mathrm{Nm}^{3}\right)$. On the other hand, the increasing of NO would suppress the reaction eqn. 2.

$$
2 \mathrm{NO}+\mathrm{O}_{2} \longrightarrow 2 \mathrm{NO}_{2}
$$

At the 8th phase, $\mathrm{HCl}$ did not further promote $\mathrm{AS}-\mathrm{AC}$ to adsorb $\mathrm{Hg}^{0}$, because it was very difficult to form active $\mathrm{Cl}$ by $\mathrm{HCl}$ in the range of experimental temperature.

Hg speciation in bypass (the 9th phase): When the simulated flue gas was switched back to the bypass at the 9th phase, the $\mathrm{Hg}^{0}$ concentration almost went back to the original $\mathrm{Hg}^{0}$ concentration level (Fig. 3). It indicated that the influence of simulated flue gas on $\mathrm{Hg}^{0}$ speciation was limited at the experimental temperature and $\mathrm{Hg}^{0}$ was the dominant speciation in the simulated flue gas without the catalytic action of carbon on the surface of AS-AC. These results matched that of reference $^{21}$. Comparing the concentrations of simulated flue gas components through the bypass and the adsorption bed, as shown in Fig. 2 and Table-3, various simulated flue gas components would always be adsorbed or changed in speciation in different degree when they passed through the AS-AC adsorption bed.

$\mathrm{Hg}^{\mathbf{0}}$ adsorption when flue gas components removed one by one: When the gas flow was switched from the bypass to the adsorption bed at the 10th phase, the $\mathrm{Hg}^{0}$ concentration immediately reduced to below $2 \mu \mathrm{g} / \mathrm{Nm}^{3}$. The conversion efficiency of $\mathrm{Hg}^{0}$ to $\mathrm{Hg}^{2+}$ was $\mathrm{ca} .85 \%$. In the simulated flue gas, the AS-AC showed good adsorption ability of $\mathrm{Hg}^{0}$. The $\mathrm{NO}_{2}$ play the key role in promoting $\mathrm{Hg}^{0}$ adsorption by ASAC. During the process of flue gas components removed from simulated flue gas, respectively, $\mathrm{NO}_{2}$ was first removed (at the $11^{\text {th }}$ phase). As shown in Fig. 2, although $\mathrm{NO}_{2}$ was removed, there was no obvious decline of $\mathrm{NO}_{2}$ concentration, which was still hold at $c a .19 .7 \mathrm{ppm}$. However, NO concentration had a slight decline. It was because the reaction (2) would happen easily when $\mathrm{NO}_{2}$ was removed. Reaction (2) consumed more $\mathrm{NO}$ and produced more $\mathrm{NO}_{2}$ simultaneously. As a result, the removal of $\mathrm{NO}_{2}$ would not have a great influence on $\mathrm{Hg}^{0}$ adsorption by AS-AC at this phase. 
As $\mathrm{O}_{2}$ was removed at the $12^{\text {th }}$ phase, the reaction (2) stopped. Correspondingly, NO concentration had a significant rise stage and $\mathrm{NO}_{2}$ concentration had a rapid decline to $c a .0 .3$ ppm. At the same time, as shown in Fig. $3, \mathrm{Hg}^{0}$ concentration at the outlet of adsorption bed rised. The $\mathrm{Hg}^{0}$ oxidation ability by gaseous $\mathrm{NO}_{2}$ disappeared gradually.

At the $13^{\text {th }}$ phase, NO was removed. The $\mathrm{Hg}^{0}$ adsorption ability of AS-AC further dropped and $\mathrm{Hg}^{0}$ concentration continuously rised. However, the curve of $\mathrm{Hg}^{0}$ concentration was in a parabolic form because the elements of $\mathrm{NO}, \mathrm{NO}_{2}$ and $\mathrm{O}_{2}$, which were already adsorbed on the surface of AS-AC through previous phases, still worked on $\mathrm{Hg}^{0}$ adsorption by AS-AC. The situation was quite different with $\mathrm{Hg}^{0}$ adsorption by AS-AC in the process when flue gas components were added, respectively. In $14^{\text {th }}$ and $15^{\text {th }}$ phases, $\mathrm{SO}_{2}$ and $\mathrm{HCl}$ were removed sequentially, which made $\mathrm{Hg}^{0}$ concentration curve appear certain wave; the $\mathrm{Hg}^{0}$ concentration increase slightly, which meant that they both had worked on promoting of $\mathrm{Hg}^{0}$ adsorption.

Though all simulated components were removed after the $16^{\text {th }}$ phase, the AS-AC still had the $\mathrm{Hg}^{0}$ adsorption ability in $\mathrm{N}_{2}$ gas. The $\mathrm{Hg}^{0}$ concentration curve continuously increased in a parabolic form. It was because that the $\mathrm{Hg}^{0}$ adsorption was fulfilled by the components of $\mathrm{NO}, \mathrm{NO}_{2}$ and $\mathrm{O}_{2}$, etc., while all the components had already been adsorbed on the surface of AS-AC after nearly $3 \mathrm{~h}$ flue gas adsorption. It was the reason that it took ca. $187 \mathrm{~min}$ for the third process of $\mathrm{Hg}^{0}$ adsorption by AS-AC to reach the original concentration and the duration was $c a .53$ min longer than that of the first phase. As shown in Fig. $3, \mathrm{Hg}^{0}$ concentration curve was symmetrically distributed around the second phase.

\section{Conclusion}

According to the experimental results and discussion, it showed that the $\mathrm{AS}-\mathrm{AC}$ had no $\mathrm{Hg}^{0}$ adsorption ability in the non-oxidizing atmosphere, such as $\mathrm{N}_{2}$ and $\mathrm{N}_{2}+\mathrm{CO}_{2}$, etc. However, the AS-AC showed strong $\mathrm{Hg}^{0}$ adsorption ability in the oxidizing atmosphere with $\mathrm{NO}_{2}$ and $\mathrm{NO}$, etc. Though the influence on homogeneous oxidation reaction of $\mathrm{Hg}^{0}$ was limited, $\mathrm{NO}_{2}$ was the key factor on heterogeneous catalytic oxidation reaction of $\mathrm{Hg}^{0}$ on the surface of AC. It was easy to form $\mathrm{NO}_{2}$ by reaction between the $\mathrm{NO}$ and $\mathrm{O}_{2}$, which was an effective way for $\mathrm{Hg}^{0}$ oxidization. It also could enhance the
$\mathrm{Hg}^{0}$ adsorption ability of $\mathrm{AC}$ through preloading $\mathrm{NO}_{2}$ on the surface. $\mathrm{Hg}^{0}$ adsorption by AS-AC, produced by physical method, was a complicated chemical adsorption process with the function of oxidising components of simulated flue gas and surface of AC. Based on these experimental results, it finely proved that the $\mathrm{Hg}^{0}$ adsorption by $\mathrm{AC}$ was a heterogeneous catalytic oxidation reaction.

\section{REFERENCES}

1. EPRI, An Assessment of Mercury Emissions from US Coal-Fired Power Plants, EPRI (1000608), Palo Alto, CA (2000).

2. J.S. Zhou, Z.Y. Luo, C.X. Hu and K.F. Cen, Energy Fuels, 21, 491 (2007).

3. C.X. Hu, J.S. Zhou, Z.Y. Luo, S. He, G.K. Wang and K.F. Cen, J. Environ. Sci., 18, 1161 (2006).

4. C.X. Hu, J.S. Zhou, S. He, Z.Y. Luo and K.F. Cen, Fuel Process. Technol., 90, 812 (2009).

5. L.S. Xu, H.C. Zen and J. Guo, Thermal Power Gen., 35, 1 (2006).

6. E.J. Granite, M.C. Freeman, W.J. O'Dowd, R.A. Hargis and H.W. Pennline, J. Environ. Manage., 84, 628 (2007).

7. W.J. O’Dowd, H.W. Pennline, M.C. Freeman, E.J. Granite, R.A. Hargis, C.J. Lacher and A. Karash, Fuel Process. Technol., 87, 1071 (2006).

8 A.A. Presto, E.J. Granite, A. Karash, R.A. Hargis, W.J. O'Dowd and H.W. Pennline, Energy Fuels, 20, 1941 (2006).

9 A.A. Presto and E.J. Granite, Environ. Sci. Technol., 40, 5601 (2006).

10. S.J. Miller, G.E. Dunham, E.S. Olson and T.D. Brown, Fuel Process. Technol., 65-66, 343 (2000).

11. T.R. Carey, O.W. Hargrove, C.F. Richardson, R. Chang and F.B. Meserole, J. Air Waste Manage. Assoc., 48, 1166 (1998).

12. C.X. Hu, J.S. Zhou, Z.Y. Luo and K.F. Cen, Energy Fuels, 25, 154 (2011).

13. C.X. Hu, PhD Thesis, Mercury Emission from Coal-Fired Power Plant in China and Stability Adsorption Mechanism of Mercury on Activated Carbon, Zhejiang University, Hangzhou, China (2007).

14. B. Hall, P. Schager and E. Lindqvist, Water Air Soil Pollut., 56, 3 (1991).

15. B. Hall, E. Lindqvist and E. Ljungstrom, Environ. Sci. Technol., 24, 108 (1990).

16. B. Hall, Water Air Soil Pollut., 80, 301 (1995).

17. K.C. Galbreath and C.J. Zygarlicke, Fuel Process. Technol., 65-66, 289 (2000).

18. H.L. Hitchcock, M.S. Thesis, Mercury Sorption on Metal Oxides, University of North Dakota (1996).

19. D.V. Radisav, R.V. Joseph and U.B. Eric, Mercury Speciation in CoalFired Power Plant Flue Gas-Experimental Studies and Model Development Final Technical Report (August 1, 2005-July 31, 2008). Cooperative Agreement Number: DE-FG26-05NT42534 (2009).

20. G.A. Norton, H.Q. Yang, R.C. Brown, D.L. Laudal, G.E. Dunham and J. Erjavec, Fuel, 82, 107 (2003).

21. C.X. Hu, J.S. Zhou, J.X. Li, Y.C. Wang, J. Zheng, M.J. Xu and Z.Y. Luo, CIESC Journal, 63, 1536 (2012). 